\title{
Does Solfinacin solve the urgency symptoms in postpartum women?
}

By

\author{
Dr Anwar Khazal Jafar ${ }^{* 1}$; Elaf Mahmood Shihab ${ }^{* 2}$; Dr Lewaa Arkan \\ Jabar $^{* 3}$; Dr Inas Taha Ahmed ${ }^{* 4}$ \\ ${ }^{* 1}$ M.B.Ch.B D.G.O ,F.I.C.O.G, specialist OBG/ Al-Elwiya Maternity teaching \\ hospital, Baghdad- Alrusafa Health Directorate/ Ministry of Health and \\ environment; ${ }^{* 2}$ Msc. pharmacology and toxicology/ Al Esraa university college; ${ }^{* 3}$ \\ M.B.Ch.B. Al-Elwiya Maternity teaching hospital, Baghdad- Alrusafa Health \\ Directorate/ Ministry of Health and environment; ${ }^{* 4}$ M.B.Ch.B D.G.O ,F.I.C.O.G, \\ Consultant specialist OBG/ Al-Elwiya Maternity teaching hospital, Baghdad- \\ Alrusafa Health Directorate/ Ministry of Health and environment, Baghdad ,Iraq.
}

\section{Abstract:}

Background: It is widely accepted that antimuscarinics are considered first-line treatment for patients with overactive bladder (OAB). However, the mechanism by which antimuscarinics improve the symptoms of $\mathrm{OAB}$ remains to be fully elucidated.Patients and methods: This study is a clinical prospective follow up study carried out in Consultancy Clinic of Al-Elwiya Maternity Teaching Hospital in Baghdad-Iraq. duration(November, 2019-April, 2020). inclusion criteria were adult postpartum women at childbearing age with symptoms of overactive bladder treated by Gynecologist with Solifenacin tablets. Results:current study showed 34\% of them were in age group 20-29 years. Mean parity history of women with OAB was (3); $32 \%$ of them had parity history of $1-3$ para and $68 \%$ of them had parity history of $4-6$ para. delivery mode for $84 \%$ of women with OAB was vaginal delivery, as well as $36 \%$ of women with $\mathrm{OAB}$ had $\leq 7$ times of urinations at day, as well as a significant decline in score 2 observed after treatment with Solifenacin $(p=0.01)$. No significant differences were observed in score 3 before and after Solifenacin treatment $(p=0.06)$. A significant decline in score 4 was observed after treatment with Solifenacin $(\mathrm{p}=0.001)$. No significant differences were observed in women with OAB before and after Solifenacin treatment, soa highly significant increase in control of urination after treatment $(\mathrm{p}<0.001)$. Conclusion: solifenacin drug is effective in reduction of overactive bladder syndrome score three months after treatment. 
keywords:solifenacin ,overactive bladder syndrome, after treatment.

\section{الخلاصة}

نبذة: تتميز فرط نشاط المثانة سريريًا بالإلحاح البولي وكثرة التبول وسلس البول مع عدم وجود عدوى. كان للمثانة المفرطة النشاط عبء كبير على صحة المر أة ونو عية حياتها.

هدف الدراسة: تقييم فعالية علاج سوليفيناسين للنساء البالغات بعد الو لادة الذين يعانون من أعر اض فرط نشاط

المرضى وطرق البحث: دراسة متابعة مستقبلية سريرية أجريت في العيادة الاستشارية لمستشفى العلوية التعليمي للأمومة في بغداد ـ العراق خلال ستة أشهر طو ال الفترة من 1 نوفمبر 2019 حتى 30 أبريل 2020 على على عينة من 50 أمر أة بالغة بعد الو لادة مع فرط نشاط المثانة المعالجة بسوليفيناسين. كان تقييم علاج سوليفيناسين يعتمد على قياس نتائج أعر اض فرط نشاط المثانة قبل وبعد العلاج.

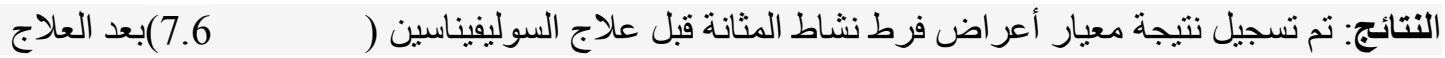
بسوليفيناسين إلى (5.6) مع وجود فرق احصائي متميزوكبير بينهما ( P P P). استمر العلاج لـ 84٪ من النساء المصابات بالمثانة المفرطة ، بينما توقف لـ 16٪ منهن. ولوحظت استجابة جيدة للعلاج لـ 88٪ من النساء المصابات بالمثانة المفرطة النشاط ، بينما لوحظت استجابة ضعيفة لـ 12\% منهن. لوحظت آثار جانبية لعلاج سوليفيناسين في 16٪ من النساء المصابات بالمثانة المفرطة النشاط. كانت الآثار الجانبية الثائعة جفاف الفم ، و الإمساك ، و عدم وضوح الرؤية.

الاستنتاجات: العامل المضاد للمسكارين السوليفيناسين هو دو اء فعال وآمن في علاج النساء المصابات بمتلازمة فرط نشاط المثانة. الكلمات المفتاحية : سوليفيناسين , متلازمة فرط نشاط المثانة. العلاج بعد ثلاث اثشر

\section{Introduction:}

Lower urinary tract symptoms (LUTS), including urgency, frequency and nocturia, are common in the general population and increase in prevalence with ageing ${ }^{1}$. Overactive bladder (OAB), the clinically defined symptom complex of urgency, with or without urgency incontinence, usually with frequency and nocturia, in the absence of infection or other pathology, ${ }^{2}$ is the most common cause of incontinence in both men and women, and the prevalence of OAB increases with age ${ }^{1}$. 
$\mathrm{OAB}$ and other forms of urinary incontinence (UI) are stigmatizing conditions with significant impacts on quality of life ${ }^{3}$ and are commonly under-reported by patients for multiple reasons, including belief that incontinence is normal post-partum or as part of ageing, or that treatment is not available ${ }^{4}$. OAB is a disorder of the filling phase of the bladder, characterized by the presence of urgency, the sudden, compelling desire to void which is difficult to defer ${ }^{2}$.

The exact underlying cause of urgency and of $\mathrm{OAB}$ remains the subject of much debate in the literature, with there being evidence for the urothelium, detrusor and brain being involved in the pathophysiology of $\mathrm{OAB}^{5}$. In those without lower urinary tract dysfunction, voiding is under voluntary control and continence is maintained by a complex interaction between the bladder and numerous areas of the brain, including the frontal and prefrontal cortices, the periaqueductal grey matter and the pontine micturition centre ${ }^{6}$. Neurological diseases, including the accumulation of white matter hyperintensities on magnetic resonance imaging, cerebrovascular disease and dementia are all strongly associated with the development of LUTS in later life ${ }^{7}$. As such, OAB cannot be considered simply as a disease of the bladder and lower urinary tract. Although conservative management options consider a whole-person approach, encompassing fluid intake, urgency suppression and bladder retraining, pharmacological agents are all directed at the bladder itself ${ }^{8}$.

\section{Patients and methods:}

\section{Patients}

This study is aclinical prospective follow up studycarried out in Consultancy Clinic of Al-Elwiya Maternity Teaching Hospital in 
Baghdad-Iraq. The duration of study was six months throughout the period from $1^{\text {st }}$ of November, 2019 till $30^{\text {th }}$ of April, 2020.

All postpartum women presented to Consultancy Clinic of Al-Elwiya Maternity Teaching Hospitalwith symptoms of overactive bladder (OAB) were the study population. The inclusion criteria were adult postpartum women at childbearing age with symptoms of overactive bladder (urinary frequency, urgency, incontinence) treated by Gynecologist with Solifenacin tablets. The exclusion criteria were younger or older age, current pregnancy, dysuria, stress incontinence, mixed incontinence with predominant stress incontinence, regular uretheral catheterization, intermittent self catheterization, urinary retention, urinary tract infection, chronic cystitis in last two weeks, bladder calculus, history of previous or exciting pelvic malignant tumors, thyroid dysfunction, diabetes mellitus, hypertension and lactation.

After eligibility to inclusion and exclusion criteria, a convenient sample of 58 adult postpartum women with $\mathrm{OAB}$ treated with Solifenacin was selected from Consultancy Clinic of Al-Elwiya Maternity Teaching Hospital after taking their approval to participate in the study. After duration of treatment withSolifenacin, the side effects of drug started in eight women and they excluded from the study and women who completed the study were 5058 adult postpartum women with OAB treated with Solifenacin.

\section{Methods}

The data collection was carried out by the researcher through direct interview with selected women, The women were assessed by the senior in Consultancy Clinic and the researcher. The diagnosis was confirmed according to symptoms of $\mathrm{OAB}$ and the senior prescribed $10 \mathrm{mg}$ or $5 \mathrm{mg}$ 
of oral Solifenacin tablet once daily for women with $\mathrm{OAB}$ for duration of at least 3 months (the dose was dependent on severity of $\mathrm{OAB}$ symptoms). After this interview, the researcher followed them for maximum duration of 6 months. The researcher reported the OAB score questions before and after treatment in addition to assessing the treatment course, response to treatment and side effects of treatment.

Statistical analysis: The data of women were analyzed by application of Microsoft excel program and Statistical Package for Social Sciences (SPSS) version 23.

\section{Results:}

This study included 50 women with overactive bladder (OAB) presented with mean age of $31.5 \pm 5.1$ years; $34 \%$ of them were in age group 20-29 years and $66 \%$ of them were in age group 30-39 years. Mean parity history of women with OAB was (3); $32 \%$ of them had parity history of 1-3 para and $68 \%$ of them had parity history of 4-6 para. The delivery mode for $84 \%$ of women with $\mathrm{OAB}$ was vaginal delivery, while $16 \%$ of them were delivered by cesarean section. All these findings were shown in table 1.

Table (1): General characteristics of women with OAB.

\begin{tabular}{|l|c|c|}
\hline Variable & No. & $\%$ \\
\hline Age mean \pm SD $(31.5 \pm 5.1$ years $)$ & \\
\hline 20-29 years & 17 & 34.0 \\
\hline 30-39 years & 33 & 66.0 \\
\hline Total & 50 & 100.0 \\
\hline Parity mean \pm SD $(3 \pm 1)$ & 16 & 32.0 \\
\hline 1-3 para & 34 & 68.0 \\
\hline 4-6 para &
\end{tabular}




\begin{tabular}{|l|c|c|}
\hline Total & 50 & 100.0 \\
\hline Mode of delivery & \multicolumn{2}{|l|}{} \\
\hline Vaginal delivery & 42 & 84.0 \\
\hline Cesarean section & 8 & 16.0 \\
\hline Total & 50 & 100.0 \\
\hline
\end{tabular}

Regarding question $1 ; 36 \%$ of women with $\mathrm{OAB}$ had $\leq 7$ times of urinations at day, $40 \%$ of them had 8-14 times of urinations and $24 \%$ of them had $\geq 15$ times of urinations before treatment with Solifenacin. For question 2; no women with $\mathrm{OAB}$ had 0 or 1 wake up for urination at night, but $16 \%$ of them had 2 times of wake up for urination at night and $84 \%$ of them had $\geq 3$ times awake up for urination at night before treatment with Solifenacin. Regarding question 3; 44\% of women with $\mathrm{OAB}$ had less than once a week sudden desire to urinate, $38 \%$ of them had once a week or more, $14 \%$ of them had once a day, $2 \%$ of them had 2-4 times a day and $2 \%$ of them had 5 times or more a day before treatment with Solifenacin. For question 4; 34\% of women with OAB had less than once a week leak of urine, $34 \%$ of them had once a week or more leak of urine, $22 \%$ of them had about once a day leak of urine, $8 \%$ of them had 2-4 times leak of urine and $2 \%$ of them had 5 times or more leak of urine before treatment with Solifenacin. As a result, the mean $\mathrm{OAB}$ score before treatment with Solifenacin was 7.6 \pm 2 . All these findings were shown in table 2.

Regarding question 5; reasons for urination were mild urge or desire $(30 \%)$,moderate urge or desire $(38 \%)$, severe urge or desire $(28 \%)$ and desperate urge or desire $(4 \%)$ before treatment with Solifenacin. For question $6 ; 18 \%$ of women with $\mathrm{OAB}$ postpone urination not more than one in 4 hours, $44 \%$ of them postpone it for about $30-60$ minutes, $26 \%$ of them postpone it for about $10-30$ minutes, $10 \%$ of them postpone it for 
few minutes and $2 \%$ of them must go immediatelybefore treatment with Solifenacin. Regarding question $7 ; 62 \%$ of women with OAB perceived poor bladder control and $38 \%$ of them perceived no control at allbefore treatment with Solifenacin. All these findings were shown in table 3.

Table (2): OAB score questions before treatment with Solifenacin.

\begin{tabular}{|c|c|c|}
\hline Variable & No. & $\%$ \\
\hline \multicolumn{3}{|c|}{$\begin{array}{l}\text { Q1: How many times do you typically urinate from waking in } \\
\text { morning to sleeping at night? }\end{array}$} \\
\hline$\leq 7$ & 18 & 36.0 \\
\hline $8-14$ & 20 & 40.0 \\
\hline$\geq 15$ & 12 & 24.0 \\
\hline Total & 50 & 100.0 \\
\hline \multicolumn{3}{|c|}{$\begin{array}{l}\text { Q2: How many times do you typically wake up to urinate from } \\
\text { sleeping at night until waking in the morning? }\end{array}$} \\
\hline 0 & 0 & - \\
\hline 1 & 0 & - \\
\hline 2 & 8 & 16.0 \\
\hline$\geq 3$ & 42 & 84.0 \\
\hline Total & 50 & 100.0 \\
\hline \multicolumn{3}{|c|}{$\begin{array}{l}\text { Q3: How often do you have a sudden desire to urinate, which i } \\
\text { difficult to defer? }\end{array}$} \\
\hline Not at all & 0 & - \\
\hline Less than once a week & 22 & 44.0 \\
\hline Once a week or more & 19 & 38.0 \\
\hline About once a day & 7 & 14.0 \\
\hline 2-4 times a day & 1 & 2.0 \\
\hline 5 times a day or more & 1 & 2.0 \\
\hline Total & 50 & 100.0 \\
\hline \multicolumn{3}{|c|}{$\begin{array}{l}\text { Q4: How often do you leak urine because you cannot defer the } \\
\text { sudden desire to urinate? }\end{array}$} \\
\hline Not at all & 0 & - \\
\hline Less than once a week & 17 & 34.0 \\
\hline Once a week or more & 17 & 34.0 \\
\hline About once a day & 11 & 22.0 \\
\hline
\end{tabular}




\begin{tabular}{|l|c|c|}
\hline $2-4$ times a day & 4 & 8.0 \\
\hline 5 times a day or more & 1 & 2.0 \\
\hline Total & 50 & 100.0 \\
\hline OAB score before Solifenacin treatment & mean \pm SD $(7.6 \pm 2)$ \\
\hline
\end{tabular}

Table (3):OAB score questions before treatment with Solifenacin.

\begin{tabular}{|c|c|c|}
\hline Variable & No. & $\%$ \\
\hline \multicolumn{3}{|c|}{ Q5: What is the reason that you usually urinate? } \\
\hline Out of convenience & 0 & - \\
\hline Because I have mild urge or & 15 & 30.0 \\
\hline $\begin{array}{l}\text { Because I have moderate urge or } \\
\text { desire }\end{array}$ & 19 & 38.0 \\
\hline Because I have severe urge or & 14 & 28.0 \\
\hline $\begin{array}{l}\text { Because I have desperate urge or } \\
\text { desire }\end{array}$ & 2 & 4.0 \\
\hline Total & 50 & 100.0 \\
\hline \multicolumn{3}{|c|}{$\begin{array}{l}\text { Q6: Once you get the urge or desire to urinate, how long can you } \\
\text { postpone it comfortably? }\end{array}$} \\
\hline No more often than one in 4 & 9 & 18.0 \\
\hline About 30-60 minutes & 22 & 44.0 \\
\hline About 10-30 minutes & 13 & 26.0 \\
\hline A few minutes (less than 10 & 5 & 10.0 \\
\hline Must go immediately & 1 & 2.0 \\
\hline Total & 50 & 100.0 \\
\hline \multicolumn{3}{|c|}{ Q7: In your opinion, how good is your bladder control? } \\
\hline Perfect & 0 & - \\
\hline Very good & 0 & - \\
\hline Good & 0 & - \\
\hline Poor & 31 & 62.0 \\
\hline No control at all & 19 & 38.0 \\
\hline Total & 50 & 100.0 \\
\hline
\end{tabular}


Regarding question $1 ; 82 \%$ of women with $\mathrm{OAB}$ had $\leq 7$ times of urinations at day, $16 \%$ of them had $8-14$ times of urinations and $2 \%$ of them had $\geq 15$ times of urinations after treatment with Solifenacin. For question 2; no women with $\mathrm{OAB}$ had 0 or 1 wake up for urination at night, but $38 \%$ of them had 2 times of wake up for urination at night and $62 \%$ of them had $\geq 3$ times awake up for urination at night after treatment with Solifenacin. Regarding question 3; 70\% of women with OAB had less than once a week sudden desire to urinate, $26 \%$ of them had once a week or more, $4 \%$ of them had once a day, no woman had 2-4 times a day and no woman had 5 times or more a day after treatment with Solifenacin. For question 4; $54 \%$ of women with OAB had less than once a week leak of urine, $46 \%$ of them had once a week or more leak of urine, no woman had about once a day leak of urine, no woman had 2-4 times leak of urine and no woman of them had 5 times or more leak of urine after treatment with Solifenacin. As a result, the mean OAB score after

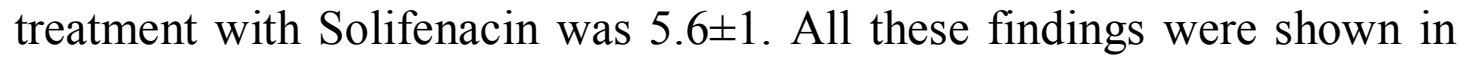
table 4.

Regarding question 5; reasons for urination were mild urge or desire $(42 \%)$,moderate urge or desire $(50 \%)$, severe urge or desire $(8 \%)$ after treatment with Solifenacin. For question $6 ; 30 \%$ of women with OAB postpone urination not more than one in 4 hours, $54 \%$ of them postpone it for about 30-60 minutes, $14 \%$ of them postpone it for about 10-30 minutes, $2 \%$ of them postpone it for few minutes and no woman must go immediatelyafter treatment with Solifenacin. Regarding question 7; 98\% of women with $\mathrm{OAB}$ perceived poor bladder control and $2 \%$ of them perceived no control at allafter treatment with Solifenacin. All these findings were shown in table 5. 
Table (4): OAB score questions after treatment with Solifenacin.

\begin{tabular}{|c|c|c|}
\hline Variable & No. & $\%$ \\
\hline \multicolumn{3}{|c|}{$\begin{array}{l}\text { Q1: How many times do you typically urinate from waking in } \\
\text { morning to sleeping at night? }\end{array}$} \\
\hline$\leq 7$ & 41 & 82.0 \\
\hline $8-14$ & 8 & 16.0 \\
\hline$\geq 15$ & 1 & 2.0 \\
\hline Total & 50 & 100.0 \\
\hline \multicolumn{3}{|c|}{$\begin{array}{l}\text { Q2: How many times do you typically wake up to urinate from } \\
\text { sleeping at night until waking in the morning? }\end{array}$} \\
\hline 0 & 0 & - \\
\hline 1 & 0 & - \\
\hline 2 & 19 & 38.0 \\
\hline$\geq 3$ & 31 & 62.0 \\
\hline Total & 50 & 100.0 \\
\hline \multicolumn{3}{|c|}{$\begin{array}{l}\text { Q3: How often do you have a sudden desire to urinate, which is } \\
\text { difficult to defer? }\end{array}$} \\
\hline Not at all & 0 & - \\
\hline Less than once a week & 35 & 70.0 \\
\hline Once a week or more & 13 & 26.0 \\
\hline About once a day & 2 & 4.0 \\
\hline 2-4 times a day & 0 & - \\
\hline 5 times a day or more & 0 & - \\
\hline Total & 50 & 100.0 \\
\hline \multicolumn{3}{|c|}{$\begin{array}{l}\text { Q4: How often do you leak urine because you cannot defer the } \\
\text { sudden desire to urinate? }\end{array}$} \\
\hline Not at all & 0 & - \\
\hline Less than once a week & 27 & 54.0 \\
\hline Once a week or more & 23 & 46.0 \\
\hline About once a day & 0 & - \\
\hline 2-4 times a day & 0 & - \\
\hline 5 times a day or more & 0 & - \\
\hline Total & 50 & 100.0 \\
\hline \multicolumn{3}{|c|}{ OAB score after Solifenacin treatment $(5.6 \pm 1)$} \\
\hline
\end{tabular}


Table (5): OAB score questions after treatment with Solifenacin.

\begin{tabular}{|l|c|c|}
\hline Variable & No. & \% \\
\hline Q5: What is the reason that you usually urinate? \\
\hline Out of convenience & 0 & - \\
\hline Because I have mild urge or & 21 & 42.0 \\
\hline $\begin{array}{l}\text { Because I have moderate urge or } \\
\text { desire }\end{array}$ & 25 & 50.0 \\
\hline Because I have severe urge or & 4 & 8.0 \\
\hline $\begin{array}{l}\text { Because I have desperate urge or } \\
\text { desire }\end{array}$ & 0 & - \\
\hline Total & 50 & 100.0 \\
\hline $\begin{array}{l}\text { Q6: Once you get the urge or } \\
\text { postpone it comfortably? }\end{array}$ & 15 & 30.0 \\
\hline No more often than one in 4 & 27 & 54.0 \\
\hline About 30-60 minutes & 7 & 14.0 \\
\hline About 10-30 minutes & 1 & 2.0 \\
\hline A few minutes (less than 10 & 0 & - \\
\hline Must go immediately & 50 & 100.0 \\
\hline Total & \multicolumn{2}{|c|}{} \\
\hline Q7: In your opinion, how good is your bladder control? \\
\hline Perfect & 0 & - \\
\hline Very good & 0 & - \\
\hline Good & 0 & - \\
\hline Poor & 49 & long \\
\hline No control at all & 1 & -0 \\
\hline Total & 50.0 \\
\hline
\end{tabular}

There was a highly significant difference in score 1 before and after treatment with Solifenacin $(\mathrm{p}<0.006)$. A significant decline in score 2 was observed after treatment with Solifenacin $(\mathrm{p}=0.01)$. No significant differences were observed in score 3 before and after Solifenacin treatment $(\mathrm{p}=0.06)$. A significant decline in score 4 was observed after treatment with Solifenacin $(\mathrm{p}=0.001)$. All these findings were shown in table 6 and figure 1. 
Table (6): Distribution of OAB scores before and after Solifenacin treatment.

\begin{tabular}{|c|c|c|c|c|c|}
\hline \multirow[t]{2}{*}{ Variable } & \multicolumn{2}{|c|}{ Before } & \multicolumn{2}{|c|}{ After } & \multirow[t]{2}{*}{$\mathbf{P}$} \\
\hline & No. & $\%$ & No. & $\%$ & \\
\hline \multicolumn{5}{|l|}{ Score 1} & \multirow[t]{4}{*}{$<0.001 *^{S}$} \\
\hline$\leq 7$ & 18 & 36.0 & 41 & 82.0 & \\
\hline $8-14$ & 20 & 40.0 & 8 & 16.0 & \\
\hline$\geq 15$ & 12 & 24.0 & 1 & 2.0 & \\
\hline \multicolumn{5}{|l|}{ Score 2} & \multirow[t]{3}{*}{$0.01 *^{S}$} \\
\hline 2 & 8 & 16.0 & 19 & 38.0 & \\
\hline$\geq 3$ & 42 & 84.0 & 31 & 62.0 & \\
\hline \multicolumn{5}{|l|}{ Score 3} & \multirow[t]{6}{*}{$0.06 * * \mathrm{NS}$} \\
\hline Less than once a week & 22 & 44.0 & 35 & 70.0 & \\
\hline Once a week or more & 19 & 38.0 & 13 & 26.0 & \\
\hline About once a day & 7 & 14.0 & 2 & 4.0 & \\
\hline 2-4 times a day & 1 & 2.0 & 0 & - & \\
\hline 5 times a day or more & 1 & 2.0 & 0 & - & \\
\hline \multicolumn{5}{|l|}{ Score 4} & \multirow[t]{6}{*}{$0.001 * * S$} \\
\hline Less than once a week & 17 & 34.0 & 27 & 54.0 & \\
\hline Once a week or more & 17 & 34.0 & 23 & 46.0 & \\
\hline About once a day & 11 & 22.0 & 0 & - & \\
\hline 2-4 times a day & 4 & 8.0 & 0 & - & \\
\hline 5 times a day or more & 1 & 2.0 & 0 & - & \\
\hline
\end{tabular}

*Chi square test, ${ }^{* *}$ Fishers exact test, $S=$ Significant, $N S=$ Not significant. 


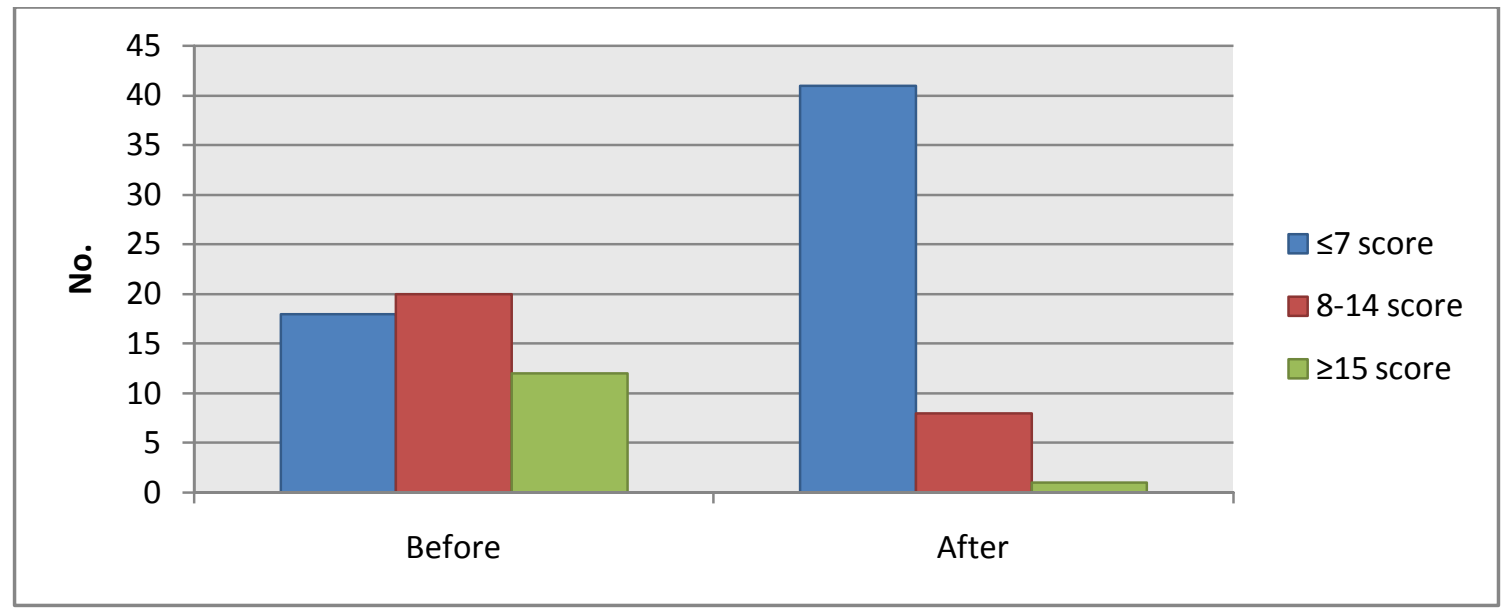

Figure 1: Distribution of score before and after treatment.

No significant differences were observed in women with $\mathrm{OAB}$ before and after Solifenacin treatment regarding question $5(\mathrm{p}=0.2)$ and question 6 $(\mathrm{p}=0.1)$. There was a highly significant increase in control of urination after treatment with Solifenacin for women with OAB $(p<0.001)$. All these findings were shown in table 7 and figure 2 .

Table (7): Distribution of OAB questions before and after Solifenacin treatment.

\begin{tabular}{|c|c|c|c|c|c|}
\hline \multirow[t]{2}{*}{ Variable } & \multicolumn{2}{|c|}{ Before } & \multicolumn{2}{|c|}{ After } & \multirow[t]{2}{*}{$\mathbf{P}$} \\
\hline & No. & $\%$ & No. & $\%$ & \\
\hline \multicolumn{5}{|l|}{ Q5 } & \multirow[t]{5}{*}{$0.2^{* N S}$} \\
\hline Because I have mild urge & 15 & 30.0 & 21 & 42.0 & \\
\hline $\begin{array}{l}\text { Because I have moderate } \\
\text { urge or desire }\end{array}$ & 19 & 38.0 & 25 & 50.0 & \\
\hline $\begin{array}{l}\text { Because I have severe urge } \\
\text { or desire }\end{array}$ & 14 & 28.0 & 4 & 8.0 & \\
\hline $\begin{array}{l}\text { Because I have desperate } \\
\text { urge or desire }\end{array}$ & 2 & 4.0 & 0 & - & \\
\hline \multicolumn{5}{|l|}{ Q6 } & \multirow[t]{5}{*}{$0.1 * \mathrm{NS}$} \\
\hline No more often than one in & 9 & 18.0 & 15 & 30.0 & \\
\hline About 30-60 minutes & 22 & 44.0 & 27 & 54.0 & \\
\hline About 10-30 minutes & 13 & 26.0 & 7 & 14.0 & \\
\hline A few minutes (less than & 5 & 10.0 & 1 & 2.0 & \\
\hline
\end{tabular}




\begin{tabular}{|l|c|c|c|c|c|}
\hline Must go immediately & 1 & 2.0 & 0 & - & \\
\hline Q7 & 31 & 62.0 & 49 & 98.0 & \multirow{2}{*}{$<0.001^{* * 5}$} \\
\cline { 1 - 5 } Poor & 19 & 38.0 & 1 & 2.0 & \\
\hline No control at all &
\end{tabular}

*Fishers exact test, ${ }^{* *}$ Chi square test, $S=$ Significant, $N S=$ Not significant.

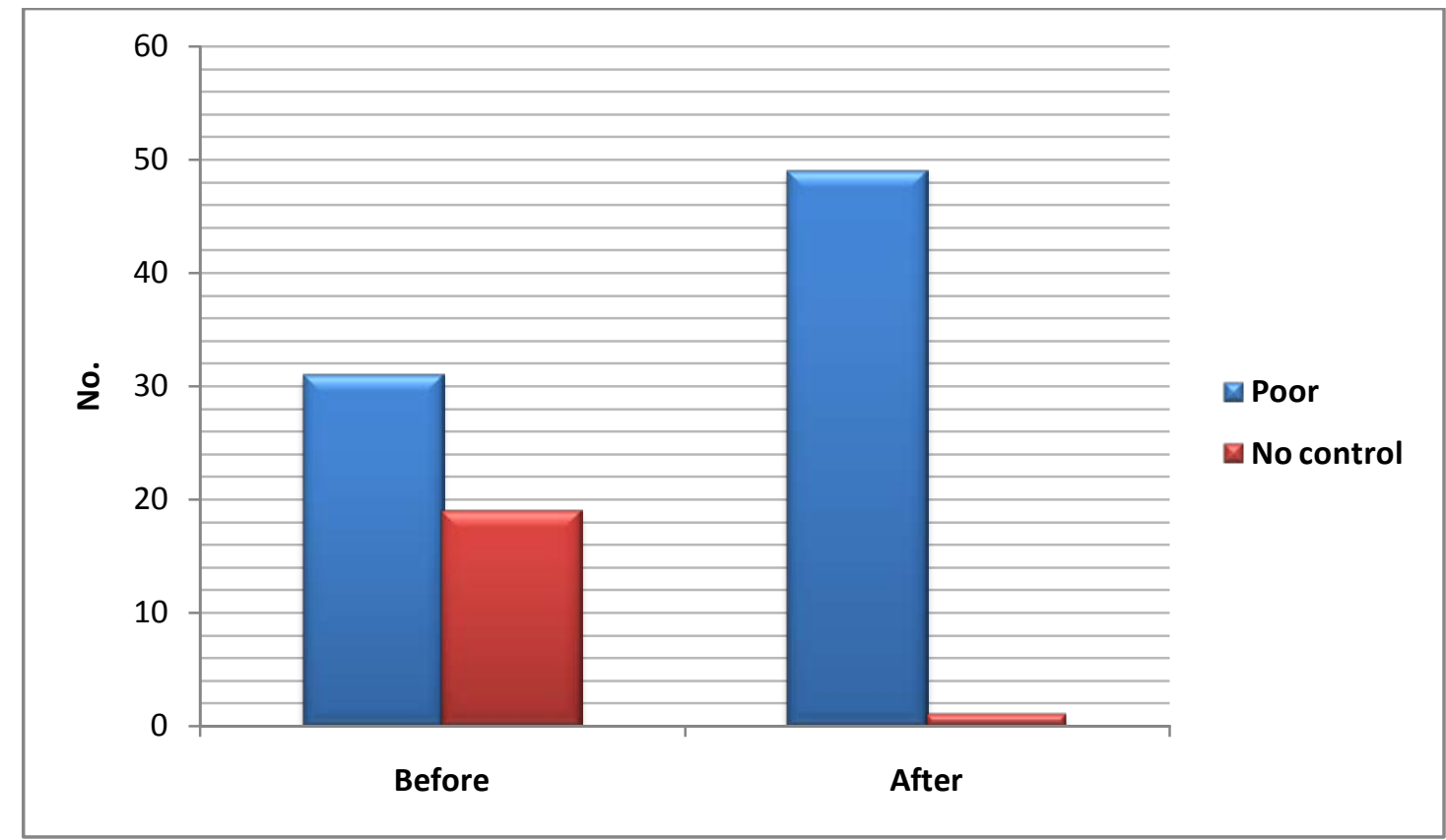

Figure 2: Distribution of control before and after treatment.

As shown in table 8; mean OAB score before Solifenacin treatment (7.6) was reduced after treatment with Solifenacint to (5.6) with a significant difference $(\mathrm{p}<0.001)$.

Table (8): Distribution of OAB score before and after Solifenacin treatment.

\begin{tabular}{|l|c|c|c|}
\hline Variable & Before & After & \multirow{2}{*}{ P } \\
\cline { 2 - 3 } & Mean \pm SD & Mean \pm SD & \\
\hline OAB score & $7.6 \pm 2$ & $5.6 \pm 1$ & $<0.001 * \mathrm{~S}$ \\
\hline
\end{tabular}

*Paired t-test, $S=$ Significant. 


\section{Discussion:}

The overactive bladder syndrome is a chronic medical disorder affecting women's quality of life ${ }^{(9)}$. Nowadays, many anti-muscarinic agents are selected in treatment of overactive bladder syndrome ${ }^{(\mathbf{1 0}, \mathbf{1 1})}$. as acetylcholine stimulates muscarinic receptors of detrusor muscle which in turn stimulates involuntary bladder contraction ${ }^{(12)}$.

Current study revealed that included women with overactive bladder syndrome were characterized by increased age, multi-parity and vaginal delivery. These findings are consistent with results of Shaker etal., ${ }^{(13)}$. study in Iraq on 34 women with urinary incontinence and found that age, parity and body mass index were the main risk factors for incontinence. However, Chae etal., ${ }^{(14)}$. study in South Korea found that age, current smoking, hyperlipidemia, cardiovascular and renal disease were the common risk factors for OAB among Korean women. Handa etal., ${ }^{(15)}$. study in USA reported that spontaneous and operative vaginal delivery was associated with higher risk of urinary incontinence and prolapse. It was shown that vaginal birth is accompanied with higher incidence of pelvic floor diseases ${ }^{(\mathbf{1 6})}$.

Present study revealed a significant decline in overactive bladder syndrome score (OABSS) after treatment with Solifenacin $(\mathrm{p}<0.001)$. This finding is similar to results of Kwon etal., ${ }^{(17)}$. twelve weeks prospective, open-label, multicenter, randomized study in South Korea on 127 patients with OAB and found that mean OABSS was significantly reduced after 12 weeks treatment with Solifenacin regardless of medication timing. This finding is also consistent with results of Cardozo etal., ${ }^{(18)}$. randomized, placebo-controlled, double-blind, efficacy trial in 105 centers in 14 European countrieswhich found that the solifenacin efficientlydecreased attacks of urgency and extent of botheringin addition to safety and effectiveness within three days of treatment. It was also 
found that OABSS is highly recommended for assessing women with overactive bladder and to evaluate the effectiveness of anticholinergic drugs etal., ${ }^{(19)}$.However, another study carried out by Yoo etal., ${ }^{(20)}$. study in South Korea reported that use of solifenacin alone had less effectiveness in reduction of OABSS mean that combination of solifenacin and tamsulocin therapy among women with overactive bladder. Hsiao etal., ${ }^{(21)}$. study in Taiwan found that female gender, high urgency severity scale score, high maximum flow rate and low postvoid residual volume were the common risk factors for better therapeutic efficacy $^{(\mathbf{2 0})}$. The solifenacin is M3 anti-muscarinicagent with higher plasma levels 3-8 hours after oral administration. It has 98\% plasma protein binding and is highly distributed to peripheral tissues with $90 \%$ bioavailability and a long half-life of 45-68 hours ${ }^{(22)}$.Many clinical trials proved the effectiveness of solifenacin in treatment of overactive bladder syndrome in women following delivery such as Chapple etal., ${ }^{(23)}$. clinical trial in Spain which found a profound decline in the mean number of voids per 24 hours and elevation in mean volume voided per void for patients taking $5 \mathrm{mg}, 10 \mathrm{mg}$, and 20 gram of solifenacin and they found also that the effectiveness and tolerability was dose dependent. Another clinical trial by Cardozo et al ${ }^{\text {(24) }}$. in UK on 12 weeks duration found a significant decline in number of nocturia, micturition and urgency after taking $10 \mathrm{mg}$ of solifenacin ${ }^{(24)}$.

In current study, number of micturition from waking to sleeping was significantly decreased after taking solifenacin by women $(\mathrm{p}<0.001)$. This finding coincides with results of Govier etal., ${ }^{(25)}$ multicenter, randomized, double-blind, parallel-group, Phase III, pivotal trial in USA on 634 patients with $\mathrm{OAB}$ and found that once daily of $10 \mathrm{mg}$ solifenacin was effective in treating $\mathrm{OAB}$ symptoms mainly frequency, incontinence and 
urgency. Our study found also a significant decline in number of nocturia attacks after taking solifenacin by women $(p=0.01)$. This finding is consistent with results of Yokoyama etal., ${ }^{(26)}$.subgroup analysis study in Japan which found that use of $10 \mathrm{mg}$ solifenacin by patients with overactive bladder decreases the nocturia episodes.

\section{Conclusion:}

1) The solifenacin anti-muscarinic agent is effective and safe drug in treatment of women with overactive bladder syndrome.

2) The solifenacin drug is effective in reduction of overactive bladder syndrome score three months after treatment.

\section{References}

1. Irwin DE, Kopp ZS, Agatep B, Milsom I, Abrams P. Worldwide prevalence estimates of lower urinary tract symptoms, overactive bladder, urinary incontinence and bladder outlet obstruction. BJU Int 2011; 108(7):1132-1138.

2. Abrams P, Artibani W, Cardozo L. Reviewing the ICS 2002 terminology report: the ongoing debate. Neurourol Urodyn 2010; 28: 287.

3. Brazell HD, O'Sullivan DM, Lasala CA. Does the impact of urinary incontinence on quality of life differ based on age? Int Urogynecol J 2013; 24: 2077-2080.

4. Khan MJ, Omar MA, Laniado M. Diagnostic agreement of the 3 Incontinence Questionnaire to video-urodynamics findings in women with urinary incontinence: Department of Urology, Frimley Health NHS Foundation Trust Wexham Park Hospital Slough, Berkshire, United Kingdom. Cent European J Urol 2018; 71(1):8491. 
5. Sakakibara R, Panicker J, Fowler CJ. Is overactive bladder a brain disease? The pathophysiological role of cerebral white matter in the elderly. Int J Urol 2014; 21: 33-38.

6. Fowler CJ, Griffiths D, de Groat WC. The neural control of micturition. Nat Rev Neurosci 2012; 9: 453-466.

7. Tadic S, Griffiths D, Murrin A. Structural damage of brain's white matter affects brain-bladder control in older women with urgency incontinence. In: Joint Annual Meeting of the International Continence Society, ICS and International Urogynecological Association, IUGA, 2010, Toronto, ON, Canada.

8. Allison SJ, Gibson W. Mirabegron, alone and in combination, in the treatment of overactive bladder: real-world evidence and experience. Ther Adv Urol 2018; 10(12):411-419.

9. Leron E, Weintraub AY, Mastrolia SA, Schwarzman P. Overactive Bladder Syndrome: Evaluation and Management. Curr Urol 2018; 11(3):117-125.

10.Hsiao SM, Liao SC, Chen CH, Chang TC, Lin HH. Psychometric assessment of female overactive bladder syndrome and antimuscarinics-related effects. Maturitas 2014; 79:428e34.

11.Hsiao SM, Chang $\mathrm{TC}$, Chen $\mathrm{CH}, \mathrm{Wu}$ WY, Lin HH. Frequent nocturia episodes, a suboptimal response to treatment, and small bladder capacity predict the need for persistent antimuscarinic therapy or re-treatment after discontinuation of antimuscarinics in female overactive bladder. Menopause 2017; 24:100e4.

12. Chapple CR. Muscarinic receptor antagonists in the treatment of overactive bladder. Urology 2002; 55(Suppl):33e46.

13. Shaker AK, Hamdan FB, Al-Saadi WI, Ghazi MJ, Ajeena I. Clinical and Urodynamic Study of Adult Female Patients with Urinary Incontinence. Iraqi JMS 2015; 13(2): 12-128. 
14.Chae J, Yoo EH, Jeong Y, Pyeon S, Kim D. Risk factors and factors affecting the severity of overactive bladder symptoms in Korean women who use public health centers. Obstet Gynecol Sci 2018; 61(3):404-412.

15. Handa VL, Blomquist JL, Knoepp LR, Hoskey KA, McDermott KC, Muñoz A. Pelvic floor disorders 5-10 years after vaginal or cesarean childbirth. Obstet Gynecol 2011; 118(4):777-784.

16. Memon HU, Handa VL. Vaginal childbirth and pelvic floor disorders. Womens Health (Lond) 2013; 9(3):265-277.

17.Kwon T, Oh TH, Choi S, Cho WY, Min K, Lee JZ, et al. Influence of Daytime or Nighttime Dosing with Solifenacin for Overactive Bladder with Nocturia: Impact on Nocturia and Sleep Quality. J Korean Med Sci 2017; 32(9):1491-1495.

18. Cardozo L, Hessdörfer E, Milani R, Arañó P, Dewilde L, Slack M, et al. Solifenacin in the treatment of urgency and other symptoms of overactive bladder: results from a randomized, double-blind, placebo-controlled, rising-dose trial. BJU Int 2008; 102(9):11201127.

19.Bunyavejchevin S. Overactive Bladder Symptom Scores responsiveness before and after anticholinergic treatment in women with overactive bladder: The pilot study. J Obstet Gynaecol Res 2017; 43(7):1189-1193.

20.Yoo C, Kim SI, Bae JH, Son JH, Oh CY, Yoon DH, et al. A prospective randomized open-label clinical observational study to assess the effectiveness of adding tamsulosin in women treated with solifenacin for overactive bladder. The Journal of Urology 2014; 191 (4S): e874. 
21.Hsiao SM, Lin HH, Kuo HC. Factors associated with a better therapeutic effect of solifenacin in patients with overactive bladder syndrome. Neurourol Urodyn 2014; 33(3):331-334.

22.Hedge SS, Choppin A, Bonhaus D. Functional role of M2 and M3 receptors in the urinary bladder of rats in vivo and in vitro. $\mathrm{Br} \mathrm{J}$ Pharmacol 2002; 120:1409-1418.

23. Chapple CR, Arano P, Bosch J. Solifenacin appears effective and well tolerated in patients with symptomatic idiopathic detrusor overactivity in a placebo- and tolterodine-controlled phase 2 dose finding study. BJU Int 2004; 93:71-77.

24.Cardozo L, Lisec M, Millard R, Kuzmin I, Drogendijk TE, Huang M, et al. Randomized, double-blind placebo controlled trial of the once daily antimuscarinic agent solifenacin succinate in patients with overactive bladder. J Urol 2004; 172(5 Pt 1):1919-1924.

25.Govier FE, Smith N, Uchida T. Efficacy and Safety of $10 \mathrm{mg}$ Solifenacin Succinate in Patients with Overactive Bladder Syndrome: Results from a Randomized, Double-Blind, PlaceboControlled Phase III Pivotal Trial. Clinical Medicine Insights: Urology 2010; 4: 11-20.

26. Yokoyama O, Yamaguchi O, Kakizaki H, et al. Efficacy of solifenacin on nocturia in Japanese patients with overactive bladder: impact on sleep evaluated by bladder diary. J Urol 2011; 186(1):170-174. 